\title{
Rejoinder to D. Brent Edwards Jr. and His Interpretation of Our Position on Democratic Education and Social Justice
}

\author{
Art Pearl • Tony Knight
}

Published online: 24 April 2010

(C) The Author(s) 2010. This article is published with open access at Springerlink.com

\begin{abstract}
We review our involvement in social justice movements and projects over the past half-century that led to our understanding of importance of democracy. We contrast our understanding based on our extensive involvement in schools, our record of accomplishments from national and state legislation. e.g., "New Careers" projects, task forces in Australian state schools, to successful inclusion of the excluded into higher education, e.g.,. Upward Bound and HEP with Critical Pedagogy which at least from its most prominent advocates is mostly talk, little action. We contrast our testable democratic theory with clearly articulated principles with Critical Pedagogy efforts to impose "truth."
\end{abstract}

Keywords Democratic education - Critical pedagogy - Social justice ·

New Careers · Important knowledge · Upward Bound · Task force ·

Disadvantaged · Deficit thinking · Postmodernism · Rights · Democratic theory ·

Democratic principles · Citizenship - Youth cultures · Aboriginal ·

Economics

Edwards does have a point in our contrasting Critical Pedagogy with democratic education. We did not do exhaustive research on Critical Pedagogy. We limited ourselves to its most visible and seemingly most authoritative spokespersons, Giroux and McLaren. But even so, our review of critical pedagogy was more thorough than his review of our interpretation of Democratic Education. The very

\footnotetext{
A. Pearl

University of California, Santa Cruz, CA, USA

e-mail: apoil@aol.com

T. Knight $(\bowtie)$

Victoria University, Melbourne, VIC, Australia

e-mail: tony-knight@bigpond.com
} 
least he could have done was to read our book (Pearl and Knight 1999) and that should have given him some cause to pause. In actuality, we work quite closely and compatibly with some critical pedagogues, of which Edwards does admit there are many versions, not all of which could be conceivably called democratic. Whether any can, remains debatable. He also allows one of our criticisms, the inaccessibility of its language. Nothing is more undemocratic than a language that excludes. However, our main point is not addressed, namely that an inaccessible language masks a paucity of thought.

First, to contrast our approach with social justice is simply not accurate historically. Our careers, starting over four decades ago, began with struggles for social justice. It is in our efforts to secure social justice that we came to understand democracy, and the impossibility of achieving a democratic outcome, such as social justice, in the absence of a democratic means.

A brief summary of what we bring to the table would be helpful here- since both of us have been long involved in all of the various efforts to advance civil rights.

Our effort to open up the "credential society" to the oppressed and denied, was first presented in Pearl and Riessman (1965), New Careers for the Poor, resulting in tens of thousands of poor, mostly African American women but also including large numbers of Hispanics and Native Americans, permanently escaping poverty and bringing new perspectives to teaching, social work, law, medicine and dentistry. ${ }^{1}$ One of those participating in "New Careers" was the mother of the artist known as Prince; while an insufficient response to Edwards' misinterpretation of our perspective on youth culture, we do however, address youth culture later.

At roughly the same time as "New Careers" in the mid 1960s we were involved with bringing hundreds of poor, oppressed and in some cases incarcerated youth to the University of Oregon in projects such as Upward Bound, HEP (high school equivalency) and Teacher Corps. Thus not only changing the lives of the "oppressed" and underserved as they subsequently became lawyers, doctors and teachers (a not particularly good TV movie, Love Mary, tells the story of one student who we recruited from a correctional institution where she had been in and out since she was 10 and who largely as a result of our efforts became a medical doctor), but also to a large extent impacting the understanding and outlook of a sizeable proportion of the traditionally admitted students to the university.

During this same period one of us (Art Pearl) was an invited speaker in 1966, to the only White House Conference on "Educating the Disadvantaged". He also served as Chair of the National Institute for Teaching of the Disadvantaged. Our understanding at that time was presented in Pearl (1972), The Atrocity of Education.

The other (Tony Knight) translated his understanding of social justice in Australia with the formation of 23, 2- year, task force and area study teams in schools; the influence of those school-based teams was subsequently revealed with

\footnotetext{
1 There were New Careers programs in medicine, dentistry, social work, education and law. The largest of the New Career programs, the Career Opportunity Program in education "existed in 132 sites with 18,000 participants in 3,000 schools enrolled in 272 colleges and universities. Fifty-four percent (of the participants were) Black, 14.2\% Hispanic, 3.7\% Native American... Nearly nine-tenths of those enrolled were members of low-income families ( $88 \%$ were female" (Carter 1977, p. 189). The success of that program is documented in Carter (1977).
} 
the use of action research methodology, where 'theory' was generated from data emerging from actual community and school-based programs (Claydon 1975; Claydon et al. 1979; Knight 2001). One of Tony's task forces included Roger Holdsworth, who as editor of the journal Connect, has for 30 years provided students with an opportunity to develop student participation programs, student action-teams, and problem-solving models (see, Holdsworth, Connect, 2009).

In addition we have both worked in prisons trying to address some of the worst social injustices imaginable. We have also worked with a wide range of civil rights advocates. In the early 1980s, Art Pearl supervised the doctorate of Huey Newton, head of the Black Panther Party. Specifically, we have both worked with indigenous populations in the United States and in Australia. Moreover, Richard Valencia (1997) who has explored in depth one of the means by which oppression is maintained, namely 'deficit' thinking, has credited Pearl with the invention of that term.

After having considerable access to power, and then losing it as administrations changed, we came to the conclusion that only a grounds-up democratic approach to change would have any permanent effect. This experience led us to the study of democratic theory. Something proponents of critical pedagogy might find a valuable addition to their analysis. A point made in our book (Pearl and Knight 1999), for example, was the devastating impact of postmodernism on democratic thought. This is a conclusion shared by one of the most imminent of participatory and deliberative democratic theorists, Benjamin Barber:

The first business of educational reformers in schools and universitiesmulticulturalists, feminists, progressives-ought to be to sever their alliance with esoteric postmodernism; with literary metatheory (theory about theory); with fun-loving, self-annihilating hyperskepticism. As pedagogy these intellectual practices court catastrophe. They proffer to desperate travelers trying to find their way between Scylla and Charybdis a clever little volume on Zeno's paradoxes. They give to people whose very lives depend on the right choices a lesson in the impossibility of judgment. They tell emerging citizens looking to legitimize their preferences for democracy that there is no intellectually respectable way to ground political legitimacy. (1992, p. 125)

As long as critical pedagogy has its roots in postmodernism, as Edwards asserts, it is not only undemocratic, but it does not lead participants to engage in a democratic process.

Edwards places us in the radical democratic theorist's camp, where we are not. Rather, we are participatory and deliberative democratic theorists (see, Pateman 1970; Barber 1984; Follett 1998; Cohen and Rogers 1983). We do, however, recognize and acknowledge some claims of radical democratic theorists, e.g., the understanding of the importance of coming to grips with the reality of a "we" versus "they" in any political economy, and thus radical democrats reassert the importance of the inalienability of specific fundamental rights for the protection of the minority, a principle ordinarily attributed to conservatives (Mouffe 1996). For those rights to exist they must be specified, something we do, and critical pedagogues in seemingly all of their manifestations, do not; another clear distinction 
between our understanding of democracy and that of the critical pedagogues. Although in fairness, it is difficult if not impossible to detect any theory in their assertion of democracy, or even a recognition of the differences in democratic theory.

In the end Edwards has not helped us find a democratic theory in critical pedagogy, nor has he answered our most powerful criticism of the undemocratic nature of critical pedagogy. Critical pedagogues claim a truth; after having defined it, they then impose it on others. In a democracy, truth is determined through open and thorough debate of opposing views. We argue that truth is the result of such deliberation. Critical pedagogues have a vanguard approach, ours is an effort to create an informed citizenry through deliberation, action, and discovery. The gulf between the two is huge.

Comments by Edwards also misrepresent how we believe democratic citizenship is achieved. While we believe that the work that Roger Holdsworth does in the journal Connect is important, we also believe that creating space, time, and opportunity for deliberations are important; Edwards and others might find these distinctions useful. But mostly we believe that students learn to be citizens by practicing citizenship through democratically changing their world. Local issues are a starting point, and ought to lead to broader themes to be researched and debated: by engaging in projects in which they have determined something needs changing, and to quote the most esteemed of critical pedagogues, Paulo Freire, students "acting on the world to change it and then reflecting on that action."

We have a four-decade record of getting students at every level to act to change their world, and to reflect on that action. Unfortunately critical pedagogy, at least as it is expressed by Giroux and McLaren is much talk, and not much action. Even in their talk, it would be important to know that when they talk democracy, just what are the principles of the democracy they propose. For example, how do they address authority (always problematic in a democracy)? How do they achieve inclusiveness? How do students learn to be democratic citizens? What inalienable rights do students have? Do they have the right to promote oppression or racism? How is the learning environment constructed to make it possible for all students to reach their fullest potential (the fundamental goal of a democracy according to democratic theorist C. B. Macpherson (1977)). And finally, but of no lesser importance, how will the avowed goal of any democracy, namely equality, be achieved?

As for youth culture, in the article we specifically addressed Giroux's books in which he discovered what all of us have know for years, that there was a capitalist bias in capitalist culture, whether it be newspapers, motion pictures or television programs. Culture like education is contested terrain. And there have been some wonderful efforts to do just that. However our concern is what is happening in classrooms, and how they provide an opportunity to engage in penetrating discussion with students; we also include the opportunity to engage in film-making, theater, and books. One of our colleagues and ally in democratic education, is Lawry Mahon (2008) who for 14 years has used IBM equipment in the most remote areas of outback Australia, to have Aboriginal youth gain literacy by writing books about Aboriginal culture. Not only has he been able to do what others have failed to do, produce literacy, but he has also made it possible for Aboriginals to gain access 
to a viable economic, political and social life, while at the same time sustaining links to and further enhance indigenous culture. Perhaps more importantly he has brought 50 pre-service teachers every year to these remote communities. These students live with, learn from, and tutor Aboriginal youth. This in turn, has had a profound impact on their understanding of teaching. This is what we mean by engaging students in youth culture.

Now we are working on ways to democratically influence student cultural activities to engage in meaningful discussion of appropriate use of cell phones, video games, i-pods and the like. We tell students they have a choice in a rapidly changing the world to play a meaningful role in creating the new world, or to be oppressed by those who will change the world. And because we have actively contended with power over these decades, running for office (Pearl ran for governor of Oregon in 1970, endorsed by both of the two senators who voted against the Vietnam War), creating legislation at local, state and national levels and otherwise being involved in social action, we have much to share with our students.

Not only is there no apparent democratic theory in critical pedagogy, there appears to be no economics in it either. McLaren, for example, advocates the overthrowing of capitalism to be replaced with what and by whom and with what kind of tactics and strategy, has never been made clear. Although lacking an understanding of history or economics, his notion of critical theory is given serious consideration by fellow critical pedagogues. By contrast, we point out to our students that if you do not invent an economy in which everyone can lead fulfilling lives, you will at best merely replace one group of oppressed with another. Pearl, for example, has worked with Herman Daly and other environmentally concerned economists to help design such an economics (see, Pearl 1971). It does provide a reason why Edwards avoided any discussion of fundamental principles informing a democracy.

Over the past four decades each institutional program, with its successes and failures, represented small steps toward developing our understanding of a democratic education. A process of osmosis, of course, does not achieve democratic education. It cannot be imposed from outside or from a top-down administration, it must be learned, by active practice, day by day (Knight 2004). Each step is a hard won combination of understanding, support, and vigorous debate. Emerging from our school/community practice and examining other data, we have developed democratic curriculum principles that by design were deliberative, negotiable, and inclusive; moreover, they were framing ideas, not prescriptive rules. Our original paper proposed a democratic curriculum practice organized around six curriculum strands (we have added a seventh). The interconnectedness of these seven different requirements is what makes a general educational theory. Finally, those of us interested in social justice have to understand it is not possible to achieve a democratic outcome, such as social justice, in the absence of a democratic process.

Open Access This article is distributed under the terms of the Creative Commons Attribution Noncommercial License which permits any noncommercial use, distribution, and reproduction in any medium, provided the original author(s) and source are credited. 


\section{References}

Barber, B. R. (1984). Strong democracy: Participatory politics for a new age. Berkeley, CA: University of California Press.

Barber, B. R. (1992). An aristocracy of everyone: The politics of education and the future of America. New York: Ballantine Books.

Claydon, L. F. (1975). The urban school. Australia: Pitman Pacific Books.

Claydon, L., Knight, T., \& Rado, M. (1979). Curriculum and Culture. Sydney: George Allen and Unwin. Cohen, J., \& Rogers, J. (1983). On democracy. Middlesex, England: Penquin Books.

Follett, M. P. (1998). (First published 1918) The New State. NY: Longmans, Green and Co.

Holdsworth, R. (2009). Connect, No. 180, December, 2009, pp. 1-4.

Knight, T. (2001). Longitudinal development of educational theory: democracy and the classroom. Journal of Educational Policy, 16(3), 249-263.

Knight, T. (2004). Student role in the learning process, Connect No. 149. October, pp. 16-19.

Macpherson, C. B. (1977). The life and times of liberal democracy. Oxford: Oxford U. Press.

Mahon, L. (2008). Story writing in remote location: Authoring culturally appropriate literature with children. In N. J. Yelland, G. Neal, \& E. Dakich (Eds.), Rethinking education with ICT: New directions for effective practice (pp. 111-119). Boston, Mass: Sense Publishing.

Mouffe, C. (1996). Radical democracy or liberal democracy. In D. Trend (Ed.), Radical democracy (pp. 19-26). New York: Routledge.

Pateman, C. (1970). Participation and democratic theory. Cambridge: Cambridge U. Press.

Pearl, A. (1971). Further thoughts on an ecological theory of value. Social Policy, Nov/Dec.

Pearl, A. (1972). The atrocity of education. New York: Dutton.

Pearl, A., \& Knight, T. (1999). The democratic classroom: Theory to inform practice. Cresskill, NJ: Hampton Press.

Pearl, A., \& Riessman, F. (1965). New careers for the poor. New York: Macmillan.

Valencia, R. R. (1997). The evolution of deficit thinking in educational thought and practice. New York: Falmer Press. 